\title{
Ownership structure and inventory policy
}

\author{
Josep A. Tribó* \\ Department of Business Administration, Carlos III University, Calle Madrid 126, 28903 Getafe, Spain
}

\begin{abstract}
This paper makes use of a database of Spanish manufacturing firms to explore the effect of a firm's ownership structure on its inventory policy. We have argued that the presence of institutional investors reduces a firm's liquidity needs and prevents overinvestment policies. This, in turn, leads to lower equilibrium inventory levels. Also, we expect, on average, less inventory investment when bank-equity financing is compared with bank-debt financing. Finally, other components of ownership structure like the number of blockholders prevent inventory overinvestment. This may have an impact on the economic cycle as more firms are floated on the stock market hence changing their ownership structure.
\end{abstract}

Keywords: Inventories; Main blockholders; Financial institutions

\section{Introduction}

In a modern corporation, inventory investment is well integrated into a firm's overall investment policy. Although the connection between financing and investment decisions is at the very center of corporate finance literature, relatively little attention has been paid to study its relationship with a firm's inventory policy. The main approach relates liquidity constraints to inventory policy (Kashyap et al., 1994; Hendel, 1996; Carpenter et al., 1998). The basic result is that those financing instruments or environments that constrain firms the most have greater impact on inventory investment. However, the connection between a firm's ownership structure and inventory policy has been totally ignored in this literature. This paper is aimed to fill this gap. We think this is a relevant issue because an increasing

\footnotetext{
${ }^{*}$ Tel.: + 34916249321 ; fax: +34916249607 .

E-mail address: joatribo@emp.uc3m.es.
}

number of firms are floated on the stock market thereby changing their ownership structure. This, in turn, may affect inventory investment and, in the end, the overall economic cycle.

We identify two channels through which ownership structure can affect a firm's inventory policy: the liquidity channel and the control channel.

The type of blockholder (banks, corporations, etc.) affects a firm's liquidity constraints. Lenders may be more willing to renew their loans to a firm owned by powerful institutional shareholders. Thus, for a firm, especially a small one with low bargaining power, having institutional investors as blockholders would clearly diminish its liquidity needs. This, in turn, should induce, on average, a lower inventory level as its need to accumulate relatively easy cashable assets like inventories to hedge liquidity shocks is reduced.

The second channel through which blockholders may affect the equilibrium inventory level is the control channel. Blockholders, contingent on their 
number and characteristics, may implement certain types of actions against the remaining shareholders' interests. These actions generally involve overinvestment to the advantage of main blockholders that, eventually, may affect the steady-state inventory levels. Under this view, inventory overinvestment is an outcome of a firm's mismanagement (Krautter, 1999). Interestingly, recent literature (Bennedsen and Wolfenzon, 2000) has examined these issues. The basic result is that minority shareholders' interests are better protected when the number of blockholders is high. This is so because the higher their number, the more likely they are to have conflicting views to seek private benefits; and the lesser likelihood of agreement on particular investment policies. This prevents overinvestment actions like those that lead to intensive inventory accumulation.

Also, the control channel justifies lower inventory investment when a firm is financed with banks' equity instead of bank debt. This is so because the control possibilities available to a bank as a shareholder are superior to those as a lender.

Finally, we expect the connection between ownership and the equilibrium inventory level to be especially relevant in a complex corporation. This type of firm requires that operations managers determine inventory level in an integrated way taking into account manufacturing, distribution, engineering, technology deployment, marketing and customer services. This is to coordinate a knowledge supply network (Mak and Ramaprasad, 2003). These additional tasks make control more difficult, especially within complex and diversified firms, and give operations managers wide scope to behave opportunistically. They can implement empirebuilding policies that generally lead to inventory overinvestment. Consequently, in this type of firm the controlling role of blockholders like banks, which monitor managers efficiently, should be especially visible through the reduction in a firm's steady-state inventory level.

We test these theoretical contentions making use of a yearly panel data sample of Spanish manufacturing firms for the period 1996-2000. Using such a low frequency does not pose a problem; this is because we expect that ownership structure has an impact on the long-term value of a firm's economic variables and, in particular, on the long-term inventory level. This latter steady-state level may be proxied perfectly by the yearly average inventory level. We find that the results fully confirm our theory. First, the presence of institutional investors like banks or other corporations reduces the average inventory level in small firms and/or in firms with certain degree of diversification. Second, the number of blockholders shows a negative relationship with a firm's inventory level. Last, a firm that has banks in its ownership structure shows a lower inventory level than a firm with a significant proportion of bank loans but without such a bank presence in its ownership structure.

The remainder of the paper is organized as follows. Section 2 develops the theoretical underpinnings as well as the hypotheses to be tested. In Section 3, the empirical analysis is carried out. The paper ends with some final remarks.

\section{Hypotheses to contrast}

We build up our hypotheses relying on two features. First, a firm's financial structure may generate liquidity pressure that a firm anticipates by investing in relatively liquid assets like inventories. This pressure is conditioned by a firm's ownership structure (liquidity channel). Second, the type and number of blockholders characterizing a firm's ownership structure prevents overinvestment policies by determining the degree of control over managers. This, in turn, affects inventory accumulation (control channel).

\subsection{Liquidity channel}

Liquidity pressure may generate stock-outs if a firm does not invest sufficiently in inventories (Pirttilä and Virolainen, 1992). Four factors that ownership structure mediates affect this pressure:

First, the structure of product market. A firm with market power is less prone to accumulate inventories in order to avoid stock-outs (Blazenko and Vandezande, 2003). This is so because this firm can modulate demand by changing prices appropriately. In this way, it can afford accumulating lower inventories as a reaction to liquidity pressure. Interestingly, the presence of institutional investors generally increases a firm's market power. This ameliorates the impact of liquidity necessities on inventory investment.

Second, the length of financing. Short-term means higher liquidity pressure. Having blockholder banks reduces liquidity pressure as it facilitates a firm with low bargaining power (e.g. a small one) the renegotiation of its debt. This allows 
a firm to maintain a low level in short-term liquid assets (e.g. inventories).

Third, the access to different financing instruments. The lower the number of financing alternatives, the higher the financing pressure. A firm with limited access to financing instruments is more willing of using inventories to hedge liquidity shocks (Calomiris et al, 1995, focusing on commercial paper). Inventories are used as "buffer" liquid assets. The presence of institutional investors, especially banks, may facilitate a firm, especially a small one, ${ }^{1}$ to issue financing instruments like commercial paper (Diamond, 1991). This, in turn, will make a small firm less dependent on inventories to buffer its liquidity necessities. In the end, a lower equilibrium inventory level is expected.

Finally, we should mention that the managers' perceptions of liquidity needs are contingent upon ownership structure. In particular, Wahal and McConell (2000) among others, find that institutional investors (i.e. banks or other corporations) promote long-term managerial vision. This smoothes out managerial reaction to local liquidity shocks which, in turn, reduces a firm's inventory level as Alfaro and Tribó (2003) shows.

In conclusion, liquidity issues suggest that the presence of institutional investors should prevent a firm, especially a small one, from accumulating large inventories.

\subsection{Control channel}

Our basic conjecture is that an excessive accumulation of inventory is a signal of mismanagement (Krautter, 1999). This means that those ownership structures that prevent collusion among blockholders and/or managers to mismanage a firm should be accompanied by lower inventory levels. Ferris et al (1998) connect a firm's adoption of efficiency-increasing performance plans to inventory shirking. Institutional investors, like banks, promote the adoption of explicit performance plans as part of their monitoring discipline. The outcome is a decrease in the steady-state inventory level.

Interestingly, the effect of control by $a$ certain type of blockholder, like banks, should be more evident in a small firm. This is so because in a large firm there are

\footnotetext{
${ }^{1}$ Economies of scale on public issues of financing instruments hinder their availability to a small firm. Thus, the presence of banks is a particular good signal for such firm public issues.
}

alternative control mechanisms like financial markets. Thus, we expect a different pattern of inventory investment in a small firm compared with that in a large one. This feature, jointly with those mentioned in the description of the liquidity channel, defines our first hypothesis:

Hypothesis 1. A small firm with banks and/or other institutional investors in its ownership structure accumulates fewer inventories than its counterparts. This lower equilibrium inventory level is not observed in a large firm.

In a complex, diversified firm, it is easier to hide those actions through which large blockholders seek private benefits by obliging overinvestment in a certain direction. Hence, for this type of firm, the presence of banks (monitoring specialists) should have great effects by preventing these value-decreasing overinvestment policies. This should be translated into a lower equilibrium inventory level.

Hypothesis 2. In a diversified firm, the presence of institutional investors like banks should lead to a lower equilibrium inventory level.

When considering the number of blockholders, a bargaining effect that shapes a firm's investment policy emerges. This effect accounts for the difficulty in reaching agreement among those blockholders that require a firm to follow specific and, in some occasions, divergent policies in order to enjoy particular private benefits of control. These policies, when they are mutually exclusive, act as an implicit protection for the minority and prevent overinvestment. This demonstrates a negative relationship between the number of blockholders and overinvestment inventory policies linked to minority expropriation.

Hypothesis 3. The number of blockholder has a negative effect on the equilibrium inventory level.

Finally, it is important to emphasize that inventories do not only provide liquidity but they may also serve as collateral in debt contracts (Tribó, 2001). Moreover, a bank-debt financed firm must adhere to a rigid payment scheme (debt contracting) which stimulates investment in liquid assets like inventories. Apart from that, the aforementioned control role is expected to be stronger for blockholder banks in preventing overinvestment initiatives than for lender banks without ownership as these latter do not have real power obliging a firm 
to follow a particular policy. This is our last hypothesis:

Hypothesis 4. A bank-equity financed firm accumulates, on average, fewer inventories than a bankdebt financed one.

\section{Empirical analysis}

\subsection{Data and preliminary evidence}

We carry out our empirical analysis making use of a sample of annual observations of Spanish manufacturing firms for the period 1996-2000. This sample is extracted from the Sistema de Análisis de Balances de Empresas Españolas (SABE) database. This database is compiled from the Spanish company register by Bureau Van Dijk. It covers companies of all sizes from all economic sectors. We have focused on those non-financial firms that have provided information on their ownership and which do not have inconsistencies in their balance sheets. The final outcome is an unbalanced panel data of 2,783 firms.

To characterize a firm's equilibrium inventory level, we use the year average inventory-to-sales ratio (INVENSALES). Variations in this ratio are a good proxy of variations in a firm's steady-state inventory level. Concerning ownership structure, this is reflected by different variables applied to the 10 largest shareholders (firm's blockholders): banks' stake (BANKOWN), other corporations' stake (CORPOWN) and individuals' stake (INDOWN). We also characterize a firm's control group (CG), which is defined as the coalition of the largest stakeholders that accounts for more than $50 \%$ of the stake, with two variables: the stake of this coalition (CGOWN) and the number of blockholders that it comprises (CGNUM). Finally, we incorporate a measure of a shareholders' contestability (CONTESTA), which is defined as the ratio of the stake not owned by the two

Table 1

Contingency analysis

\begin{tabular}{|c|c|c|c|c|}
\hline & INVENSALES $>$ Mean $^{\text {b }}$ & 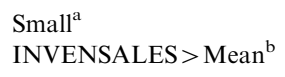 & 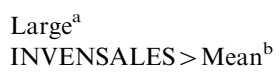 & 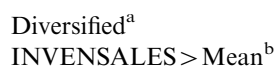 \\
\hline BANKOWN $>$ Mean $^{\text {b }}$ & $9.96 \%$ & $9.52 \%$ & $8.43 \%$ & $12.90 \%$ \\
\hline BANKOWN $\leqslant$ Mean $^{\text {b }}$ & $10.44 \%$ & $11.58 \%$ & $5.40 \%$ & $11.74 \%$ \\
\hline Pearson $^{c}$ & 0.80 & 0.68 & 0.23 & 0.84 \\
\hline BANKOWN $>50 \%$ & $4.04 \%$ & $0 \%$ & $3.03 \%$ & $7.14 \%$ \\
\hline BANKOWN $\leqslant 50 \%$ & $10.48 \%$ & $11.63 \%$ & $5.52 \%$ & $11.80 \%$ \\
\hline Pearson $^{c}$ & $0.037^{* *}$ & $0.114^{*}$ & 0.532 & 0.59 \\
\hline CORPOWN $>$ Mean $^{\text {b }}$ & $9.87 \%$ & $10.25 \%$ & $4.48 \%$ & $11.58 \%$ \\
\hline CORPOWN $\leqslant$ Mean $^{\mathrm{b}}$ & $11.21 \%$ & $12.76 \%$ & $6.81 \%$ & $12.07 \%$ \\
\hline Pearson $^{c}$ & $0.019^{* *}$ & $0.052^{* *}$ & $0.007^{* * *}$ & 0.759 \\
\hline INDOWN $>$ Mean $^{\text {b }}$ & $10.23 \%$ & $11.84 \%$ & $4.8 \%$ & $10.83 \%$ \\
\hline INDOWN $\leqslant$ Mean $^{\text {b }}$ & $10.6 \%$ & $11.05 \%$ & $6.25 \%$ & $12.49 \%$ \\
\hline Pearson $^{\mathrm{c}}$ & 0.519 & 0.556 & $0.087^{*}$ & 0.289 \\
\hline CGNUM $>$ Mean $^{\text {b }}$ & $10.06 \%$ & $11.91 \%$ & $7.24 \%$ & $12.77 \%$ \\
\hline CGNUM $\leqslant$ Mean $^{\mathrm{b}}$ & $10.50 \%$ & $11.44 \%$ & $5.19 \%$ & $11.57 \%$ \\
\hline Pearson $^{\mathrm{c}}$ & 0.561 & 0.768 & $0.085^{*}$ & 0.568 \\
\hline BANKLEND $>$ Mean $^{\text {b }}$ & $9.58 \%$ & $12.05 \%$ & $7.79 \%$ & $16.48 \%$ \\
\hline BANKLEND $\leqslant$ Mean $^{\text {b }}$ & $10.50 \%$ & $11.45 \%$ & $4.98 \%$ & $11.21 \%$ \\
\hline Pearson $^{\mathrm{c}}$ & 0.371 & 0.74 & $0.01^{* * * *}$ & $0.04^{* *}$ \\
\hline ROA $>$ Mean $^{\mathrm{b}}$ & $7.06 \%$ & $10.59 \%$ & $4.29 \%$ & $9.68 \%$ \\
\hline $\mathrm{ROA} \leqslant$ Mean $^{\mathrm{b}}$ & $13.10 \%$ & $12.74 \%$ & $7.56 \%$ & $13.71 \%$ \\
\hline Pearson $^{\mathrm{c}}$ & $0.000^{* * *}$ & $0.098^{* * *}$ & $0.000^{* * *}$ & $0.009^{* * *}$ \\
\hline
\end{tabular}

\footnotetext{
${ }^{a}$ Small firms mean that LEMPLOY $<4$, large firms have LEMPLOY $>4$ and diversified firms are those whose main activities are in more than one sector. We use 4 as threshold as it is the mean value of LEMPLOY variable. All the variables are defined in the text.

${ }^{\mathrm{b}}$ Mean values for the corresponding sector and year.

${ }^{c}$ Pearson test. The null hypothesis is that both percentages of firms are statistically independent. ${ }^{*} 90 \%$ significant, ${ }^{* *} 95 \%$ significant, **** $99 \%$ significant.
} 
largest stakeholders to the difference in the stake of the two largest stakeholders. The higher this variable, the more likely it is for the largest blockholder to lose control of the firm.

To avoid spurious correlations, we introduce different controls. First, financing pressure is characterized by the debt to equity ratio (DEQUITY). Second, a firm's profitability is measured by the return on assets (ROA) which is the ratio of profits before interest and taxes to the total assets. Third, market structure is given by the Herfindahl index (HERFINDAHL). ${ }^{2}$ Fourth, size effects are controlled with a variable (LEMPLOY), which is the number of employees on a log scale. Last, to contrast Hypothesis 4, we use BANKLEND, that is, the ratio of bank debt to total debt.

To provide preliminary evidence of our theoretical contentions we conduct different tests of mean differences that are shown in Table 1.

Table 1 shows the proportion of firms with INVENSALES larger than the mean for the sector and compares this proportion in different scenarios. These are defined by the value of different variables compared to the mean for the sector. In columns 2 , 3 and 4, we focus on small, large and diversified firms (see the table for definitions).

We find that, on average, a firm with stakeholdings from banks higher than the mean for the sector does not show lower INVENSALES. However, this ratio is lower when stakeholder banks account for more than $50 \%$ (bank-controlled firms) and especially so for small firms. This conforms to Hypothesis 1. Also, lender banks, contrary to blockholder banks, do not generate such an effect on inventories. This is consistent with Hypothesis 4. Concerning other investors, corporations have a negative effect on inventory accumulation, but individual investors do not.

Finally, control variables show that the more profitable firms adjust better their production in relation to their sales (lower INVENSALES).

\subsection{Methods and results}

To extend the previous analysis, we rely on regression techniques and we take advantage of the panel data structure of our sample. Our basic specification is as follows:

$$
\begin{aligned}
\text { INVENSALES }_{i t}= & \alpha+\beta_{1} \text { BANKOWN }_{i t} \\
& +\beta_{2} \text { CORPOWN }_{i t}+\beta_{3} \text { INDOWN }_{i t}
\end{aligned}
$$

\footnotetext{
${ }^{2}$ This is the square root of the sum for all the firms in a sector of their sales market share to the square.
}

$$
\begin{aligned}
& +\beta_{4} \text { CGNUM }_{i t} \\
& +\beta_{5} \text { CGOWN }_{i t}+\beta_{6} \text { CONTESTA }_{i t} \\
& +\beta_{7} \text { LEMPLOY }_{i t}+\beta_{8} \text { ROA } \\
& +\beta_{9} \text { DEQUITY }_{i t} \\
& +\beta_{10} \text { HERFINDAHL }_{i t}+u_{i}+\psi_{t}+\varepsilon_{i t},
\end{aligned}
$$

where $u_{i}$ accounts for the unobservable heterogeneity, $\psi_{t}$ is a temporal error term and $\varepsilon_{i t}$ is a whitenoise error term.

We recognize the possibility that $u_{i}$ may be correlated with a firm's ownership structure (fixed effects). To investigate whether this is the case, we conduct Hausman tests in each specification. ${ }^{3}$ Additionally, for those specifications where fixed effects are not shown, we have conducted a second Hausman test. This compares random-effects estimations (consistent but less efficient) with crosssection regressions (efficient but may not be consistent). This second test shows that there are no systematic differences between the coefficients of both estimations. Thus, we stick to the simple regression estimation in these cases (columns 1 and 2 of Table 2).

Table 2 presents four regressions. In column 1 there is the cross-section regression for the whole sample, whereas in columns 2 and 3 we restrict the sample to small $($ LEMPLOY $<4)$ and large firms $($ LEMPLOY $>4){ }^{4}$ Finally, column 4 shows the results for diversified firms (those whose main activities are in more than one sector). Hausman test reveals that estimations in columns 3 and 4 should be made using fixed-effects techniques, while those of columns 1 and 2 are simple regressions. Also, we address a multicollinearity problem between CORPOWN and INDOWN variables. To do so, we use the residual term of an estimation of INDOWN following specification (1) as a substitute of this variable (orthogonalization). Finally, tests of fitness reveal that all models are significant.

We find that there is a clear negative relationship between the presence of institutional investor (banks or corporations) and its INVENSALES. Moreover, this is particularly true for small firms

\footnotetext{
${ }^{3}$ The Hausman test studies whether systematic differences exist between those coefficients of the fixed-effects estimation and those of the random-effects estimations. If there are systematic differences, the only consistent estimator is the fixed-effects one. If not, the best alternative to use is the random-effects estimation.

${ }^{4} \mathrm{We}$ use 4 as the threshold value of LEMPLOY because it is the mean value for this variable.
} 
Table 2

Regressions on INVENSALES

\begin{tabular}{|c|c|c|c|c|}
\hline & All (robust regression) $)^{\mathrm{a}, \mathrm{b}}$ & Small (robust regression) ${ }^{\mathrm{a}, \mathrm{b}}$ & Large (fixed effect) ${ }^{\mathrm{a}}$ & Diversified (fixed effect) ${ }^{a}$ \\
\hline BANKOWN & $-0.015^{* * *}(4.57)$ & $-0.035^{* * *}(5.76)$ & $-0.010(0.58)$ & $-0.121^{* * *}(2.54)$ \\
\hline CORPOWN & $-0.010^{* *}(3.77)$ & $-0.020^{* *}(3.58)$ & $-0.000(0.11)$ & $-0.041^{* * *}(4.02)$ \\
\hline INDOWN & $0.060^{*}(1.44)$ & $0.007^{*}(0.72)$ & $0.019^{* * *}(4.47)$ & $0.028^{* *}(1.79)$ \\
\hline CGNUM & $-0.091^{*}(1.61)$ & $-0.165^{*}(1.65)$ & $0.045(0.65)$ & $-0.974^{* * *}(3.2)$ \\
\hline CGOWN & $-0.005^{*}(0.75)$ & $-0.018(1.43)$ & $0.026^{* * *}(3.01)$ & $0.019(0.44)$ \\
\hline CONTESTA & $-0.186(0.23)$ & $-2.11^{*}(1.62)$ & $0.634(0.78)$ & $5.409^{* *}(1.83)$ \\
\hline LEMPLOY & $-0.893^{* * *}(8.16)$ & $-1.550^{* * *}(4.02)$ & $-0.122(0.38)$ & $0.205(0.26)$ \\
\hline ROA & $-3.874^{* * *}(4.00)$ & $-6.615^{* * *}(3.10)$ & $-0.037(0.04)$ & $0.625(0.19)$ \\
\hline DEQUITY $\times 100^{\mathrm{c}}$ & $0.023(1.08)$ & $0.060(0.47)$ & $-0.000(0.02)$ & $-0.782(0.36)$ \\
\hline HERFINDAHL & $-0.007^{* *}(1.99)$ & $-0.900(1.10)$ & $0.028(1.36)$ & $-0.087^{* *}(2.43)$ \\
\hline Constant & $6.826^{* * *}(4.57)$ & $9.700^{* * *}(5.46)$ & $0.323(0.13)$ & $0.988(0.16)$ \\
\hline Number of observations & 5248 & 2419 & 2829 & 904 \\
\hline Hausman test & $24.71(0.133)$ & $21.78(0.151)$ & $44.08(0.000)$ & $31.05(0.055)$ \\
\hline Hausman test ${ }^{\mathrm{d}}$ & $17.72(0.606)$ & $21.18(0.387)$ & & \\
\hline Log (likelihood) & -18616.031 & -9152.952 & -4806.636 & -1939.298 \\
\hline Fitness of the model ( $\mathrm{F}$ test) & $7.15(0.000)$ & $5.92(0.000)$ & $4.49(0.000)$ & $4.01(0.000)$ \\
\hline
\end{tabular}

and/or diversified ones, but not for large firms. This conforms to Hypotheses 1 and 2. Also, increases in stakeholdings, when stakeholders are banks, show larger negative effects on the average inventory level than when they are corporations. This is a reflection of the fact that banks are especially able to provide liquidity and/or prevent overinvestment policies (control role). Additionally, we have founded that the presence of individual investors does not stimulate inventory disinvestment.

Once we focus on other dimensions of a firm's ownership structure, we do observe a negative relationship between the number of blockholders in the CG and a firm's inventory level. This is especially clear for diversified firms where minority expropriating possibilities are higher. This fully conforms to Hypothesis 3 .

Concerning control variables, financial structure does not explain inventory investment once ownership structure has been taken into account. Finally, a low level of inventory to sales is shown in highly profitable firms and/or large ones and/or with high market power.

\subsubsection{Bank-equity financing versus bank-debt financing}

To investigate Hypothesis 4, we conduct a multinomial logit estimation on a variable $V$ that encompasses all the events resulting from the
Table 3

Definition of dependent variable $V$

\begin{tabular}{llll}
\hline Variable $V$ & DINV $=1^{\mathrm{a}}$ & DBANK $=1^{\mathrm{a}}$ & DBLOAN $=1^{\mathrm{a}}$ \\
\hline$V=7$ & 1 & 1 & 1 \\
$V=6$ & 1 & 1 & 0 \\
$V=5$ & 1 & 0 & 1 \\
$V=4$ & 1 & 0 & 0 \\
$V=3$ & 0 & 1 & 1 \\
$V=2$ & 0 & 1 & 0 \\
$V=1$ & 0 & 0 & 1 \\
$V=0$ & 0 & 0 & 0 \\
\hline
\end{tabular}

${ }^{\mathrm{a}}$ DINV $=1(0)$ if INVENSALES $>(\leqslant)$ Mean; DBANK $=1$ (0) if BANKOWN $>(=)$ Mean; DBLOAN $=1(0)$ if BANKLEND $>(\leqslant)$ Mean, where Mean is the mean value for the corresponding sector and year. All the variables are defined in the text.

combination of major inventory changes together with significant changes in a firm's bank financing (equity or debt). This allows us to isolate the effects of changes in banks' stakes with those in banks' loans given the potential strong connection between both variables. We consider as independent variables those of specification (1) but without including BANKOWN, as it is integrated in dependent variable $V$. This latter variable is defined in Table 3. 
Table 4

Multinomial logit analysis

\begin{tabular}{lll}
\hline & Prob $(\mathrm{DINV}=1)^{\mathrm{a}}$ condit. to $(\%)$ & T test of means $^{\mathrm{b}}$ \\
\hline DBANK $=1 \&$ DBLOAN $=0^{\mathrm{a}}$ & 1.220 & $46.054(0.000)$ \\
DBANK $=0 \& D B L O A N=0^{\mathrm{a}}$ & 8.088 & $5.133(0.000)$ \\
DBANK $=0 \& D B L O A N=1^{\mathrm{a}}$ & 7.522 & $37.595(0.000)$ \\
DBANK $=0 \& D B L O A N=0^{\mathrm{a}}$ & 8.088 & \\
DBANK $=1 \& D B L O A N=0^{\mathrm{a}}$ & 1.220 & \\
DBANK $=0 \& D B L O A N=1^{\mathrm{a}}$ & 7.522 & \\
\hline
\end{tabular}

${ }^{a}$ DINV $=1 \quad(0)$ if INVENSALES $>(\leqslant)$ Mean; DBANK $=1 \quad(0)$ if BANKOWN $>(=)$ Mean; DBLOAN $=1 \quad(0)$ if BANKLEND $>(\leqslant)$ Mean, where Mean is the mean value for the corresponding sector and year. All the variables are defined in the text.

${ }^{\mathrm{b}} \mathrm{T}$ statistics in parentheses.

From the multinational logit specification, we can compute the probability of different results for $V$ (we denote $\mathrm{Pi}=\operatorname{Prob}(V=i)$ ). From $\mathrm{Pi}$ we can obtain conditional probabilities of major changes in INVENSALES (DINV = 1) contingent on significant changes in banks' stake (DBANK $=1$ ), in one case, and in banks' loans (DBLOAN $=1$ ), in the other. In particular, Prob(DINV $=1 / \mathrm{DBANK}=$ $1 \&$ DBLOAN $=0)=P_{6} /\left(P_{2}+P_{6}\right), \quad$ Prob(DINV $=$ $1 / \mathrm{DBANK}=0 \& \mathrm{DBLOAN}=1)=P_{5} /\left(P_{1}+P_{5}\right)$ and so on, for other marginal probabilities. Also, in order to better separate the effects due to changes in bank equity from those due to changes in bank debt, we have focused on those firms where their debtholder banks are not shareholders.

Table 4 shows that a firm with a banks' stake higher than the mean for the sector is less likely to increase its inventory ratio above the mean value for the sector than a firm without such a stake. The same can be said when focusing on bank loans. But, interestingly, when we compare bank-equity financing with bank-debt financing, we do observe that the effect of the former is larger than the latter (lower probability of a high INVENSALES when banks' stakes are large than what banks' loans are: 1.220 versus 7.522 ). This conforms to Hypothesis 4.

\section{Conclusions}

This paper shows the relevance of a firm's ownership structure on its definition of inventory policy. We find that a firm with institutional investors (banks and other corporations) as blockholders shows lower average inventory levels when compared with its counterparts who do not have such investors. We explain this result in terms of the provision of liquidity as well as the tight control exercised by these types of blockholders, especially in small firms and/or diversified ones. Also, by comparing bank-equity financing with bank-debt financing, we argue that the control possibilities available to a bank as a shareholder are superior to those as a lender. This justifies the reduced probability of a firm overinvesting in inventories in the former case, in comparison with the latter. Finally, we identify the number of blockholders as a dimension of a firm's ownership structure that affects its inventory level. This is so because the higher this number, the greater the difficulty in reaching agreements among different blockholders and the manager so as to pursue overinvestment policies to seek private benefits. This reduction in overinvestment is translated into a lower inventory level. We prove these contentions making use of a database of Spanish manufacturing firms for the period 1996-2000. Although these years correspond to expansive years, we expect that in recessive periods the result of a reduction in the average inventory level related to banks ownership should be even stronger. This is so because monitoring and control by banks so as to prevent overinvestment is particularly important in recessive periods.

Finally, we mention two ways of extending the paper. First, it may be interesting to focus the study on sectors divided by growth rate. We expect to obtain a more visible effect of a firm's ownership structure on inventories in growth sectors than in non-growth sectors. Second, it may be enlightening to investigate whether changes in ownership structure, once a firm has been floated on the stock market, could have an impact on its inventory investment. This may well affect the overall economic cycle as more firms are floated on the stock market. This will be the subject of future research. 


\section{Acknowledgements}

The author wish to thank to José Alfaro and María Gutiérrez for their many helpful suggestions on earlier drafts of this paper. This paper has been presented at the 2004 ISIR congress in Budapest. Financial support provided by the project (SEC) 2001-0445 is gratefully acknowledged. Any error is my own responsibility.

\section{References}

Alfaro, J., Tribó, J.A., 2003. Operations manager turnover and inventory fluctuations. International Journal of Production Economics 81-82, 51-58.

Bennedsen, M., Wolfenzon, D., 2000. The balance of power in close corporations. Journal of Financial Economics 58 (1-2), 113-139.

Blazenko, G., Vandezande, K., 2003. Corporate holdings of finished goods inventories. Journal of Economics and Business 55, 255-266.

Calomiris, C.W., Himmelberg, C.P., Wachtel, P., 1995. Commercial paper, corporate finance, and the business cycle: a microeconomic perspective. Carnegie-Rochester Conference Series on Public Policy 42, 203-250.

Carpenter, R.E., Fazzari, S.M., Petersen, B.C., 1998. Financing constraints and inventory investment: a comparative study with high-frequency panel data. The Review of Economics and Statistics 80 (4), 513-519.

Diamond, D., 1991. Monitoring and reputation: the choice between bank loans and directly placed debt. Journal of Political Economy 99, 688-721.

Ferris, S.P., Kumar, R., Sant, R., Sopariwala, P.R., 1998. An agency analysis of the effect of long-term performance plans on managerial decision making. Quarterly Review of Economics and Finance 38 (1), 73-91.

Hendel, I., 1996. Competition under financial distress. Journal of Industrial Economics 44, 309-324.

Kashyap, A.K., Lamont, O.A., Stein, J.C., 1994. Credit conditions and the cyclical behavior of inventories. Quarterly Journal of Economics 109 (3), 565-592.

Krautter, J., 1999. Inventory theory: new perspectives for corporate management. International Journal of Production Economics 59, 129-134.

Mak, K.T., Ramaprasad, A., 2003. Knowledge supply network. The Journal of the Operational Research Society 54 (2), 175-183.

Pirttilä, T., Virolainen, V., 1992. An overview of the state and problems of inventory management in Finland. International Journal of Production Economics 26 (1-3), 217-220.

Tribó, J.A., 2001. Inventories, financial structure and market structure. International Journal of Production Economics 71, 79-89.

Wahal, S., McConell, J.J., 2000. Do institutional investors exacerbate managerial myopia? Journal of Corporate Finance 6, 307-329. 